\title{
Nutritional composition of rice bran submitted to different stabilization procedures
}

\author{
Simone Aparecida dos Santos Conceição Faria ${ }^{1, *}$, Priscila Zaczuk Bassinello², \\ Marilene de Vuono Camargo Penteado ${ }^{1}$
}

\author{
${ }^{,}$Department of Food and Experimental Nutrition, Faculty of Pharmaceutical Sciences, University of São Paulo, \\ ${ }^{2}$ EMBRAPA Rice and Beans Research Center
}

\begin{abstract}
In order to inactivate enzymatic deterioration, whole rice bran samples were subjected to two stabilization methods. Changes in nutritional value in terms of, concerning chemical composition, minerals and fatty acid content, were evaluated to supplement existing data and promote the utilization of rice bran in the human diet. The following homemade heat treatments were applied: roasting on a conventional stove or heating in a microwave oven. Based on the results, the different heating methods affected sample composition, since the levels of some nutrients of treated samples showed significant changes $(\mathrm{p}<0.05)$ compared to corresponding raw samples. The rice bran treated on a conventional stove produced products with lower moisture $(5.14 \pm 0.10 \mathrm{~g} / 100 \mathrm{~g})$ and nutrients such as sodium $11.8 \%$; palmitic acid $9.9 \%$ and stearic acid $8.1 \%$. The microwave oven procedure resulted in better nutrient preservation, with slightly higher moisture content $(6.28 \pm 0.10 \mathrm{~g} / 100 \mathrm{~g})$, and appears to be a practical and rapid tool for home heat stabilization of rice bran.
\end{abstract}

Uniterms: Rice bran/nutritional composition. Rice bran/nutritional value. Rice bran/heat treatment. Oryza sativa/phytochemistry. Human diet. Fatty acids/in food. Minerals/in food. Enzymatic inactivation.

\begin{abstract}
A fim de inativar a deterioração enzimática, as amostras de farelo de arroz foram submetidas a dois métodos de estabilização. As mudanças do valor nutricional, no que se refere a composição química, os minerais e o conteúdo de ácidos graxos, foram avaliadas para adicionar mais informações aos dados existentes e promover a utilização de farelo de arroz na dieta humana. Os seguintes tratamentos caseiros por calor foram aplicados: torra em forno convencional ou de aquecimento em forno de micro-ondas. Com base nos resultados, os diferentes métodos de aquecimento afetaram a composição das amostras, já que os níveis de alguns nutrientes mostraram alterações significativas $(\mathrm{p}<0,05)$, comparado com as amostras cruas correspondentes. $\mathrm{O}$ farelo de arroz tratado em fogão convencional forneceu produtos com menos umidade $(5,14 \pm 0,10 \mathrm{~g} / 100 \mathrm{~g})$ e nutrientes, tais como: de sódio $11,8 \%$; ácido palmítico 9,9\% e ácido esteárico $8,1 \%$. O procedimento de forno de micro-ondas resultou em melhor preservação dos nutrientes, com teor de umidade um pouco maior $(6,28 \pm 0,10 \mathrm{~g} / 100 \mathrm{~g})$, o que parece ser uma ferramenta prática e rápida no tratamento térmico caseiro para o farelo de arroz.
\end{abstract}

Uniterms: Farelo de arroz/composição nutricional. Farelo de arroz/valor nutricional Farelo de arroz/ tratamento térmico. Oryza sativa/fitoquímica. Dieta humana. Tratamento térmico. Ácidos graxos/em alimentos. Minerais/em alimentos. Inativação enzimática.

\section{INTRODUCTION}

Rice bran is a by-product of the rice (Oryza sativa L.) processing industry. In India and other countries,

\footnotetext{
*Correspondence: S. A. S. Conceição Faria. Departamento de Alimentos e Nutrição Experimental, Faculdade de Ciências Farmacêuticas, Universidade de São Paulo. Av. Prof. Lineu Prestes, 580, B13A, 05508-900 - São Paulo-SP, Brasil. E-mail: sinett@usp.br
}

approximately one million tons of bran are produced annually and used predominantly for animal feed (Zhongli et al., 2005; Sumantha et al., 2006). Recently, the use of rice bran is gaining importance in many studies due to the fact that, during the processing of whole rice, large amounts of the grain's outer layers are removed, raising the concentration of nutrients in the bran and rendering it an important source of nutrients for the food industry 
and human consumption (Xu, Godber, 1999; Carvalho, Bassinello, 2006; Parrado et al., 2006; Renuka, Arumughan, 2007; Imsanguan et al., 2008; Lilitchan et al., 2008). However, its utilization is limited due to enzymatic activity after rice dehulling. Rice bran is rich in lipids and intense lipase activity in the presence of endogenous lipoxygenase causes rapid deterioration of these lipids by rancification (Paucar-Menacho et al., 2007). Because of lipid susceptibility, the commercial use of rice bran requires enzymatic inactivation immediately after bran separation to avoid fatty acid liberation, extend its shelf life and allow its commercialization for human consumption (Wada, 2001). Enzymatic inactivation can be achieved by heating to high temperatures for a short period (Ramezanzadeh et al., 1999). Some industries extrude the defatted rice bran for use mainly as animal feed. In countries such as Brazil, stabilized rice bran for human consumption is not widely available at supermarkets. Consequently, consumers looking for the product have to acquire it raw directly from rice processing companies and subject it to heat treatment in a conventional stove or microwave oven. These treatments are known as homemade stabilization methods. The rice bran has been introduced into a "multi-mixture" of toasted flour (generally in home-made form) consisting of food industry waste, as part of a Brazilian social program to restore the health of malnourished children (Silva et al., 2006). However, little is known about the influence of these processes on the nutritional value of rice bran. Therefore, this work was conducted to evaluate the effect of two different stabilization procedures on the level of preservation of the nutritional composition of rice bran, and to provide further information about a potential food ingredient for the human diet. From a commercial perspective, when there is a growing market for rice bran with added value and more scientific information available about its benefits, industries are expected to show more interest in processing the product for human consumption besides its current use as animal feed.

\section{MATERIAL AND METHODS}

The stabilization treatment defined as "homemade" (roasting on a conventional stove or heating in a microwave oven) was performed using rice bran samples provided by EMBRAPA Rice and Beans Research Center, county of Santo Antônio de Goiás - Goiás state, where the upland rice cultivar BRS Primavera was grown at its Capivara Farm. The crop was harvested between April and May 2006, observing the best "harvest point" at which around $2 / 3$ of the panicle is ripe. Approximately $120 \mathrm{~kg}$ of the rice harvested (paddy rice) was cleaned, purged with phosphine gas to prevent insect infestation, and stored in a room under controlled temperature $\left(25^{\circ} \mathrm{C}\right)$. Rice samples were subjected to the standard process to separate bran using a rice mill (Suzuki) at the Rice Breeding Program Laboratory. Rice bran samples were then prepared for the stabilization treatments and subsequent analyses.

\section{"Homemade" treatments}

Rice bran provided by EMBRAPA was divided into three samples: whole rice bran (WRB) or crude (control); microwaved rice bran (MRB) and roasted rice bran (RRB). $200 \mathrm{~g}$ of MRB was treated in a microwave oven (Samsung $-950 \mathrm{~W}$ ) set at level 5 or medium power for 6 minutes (around $78^{\circ} \mathrm{C}$ ) and manually mixed every 2 minutes. The RRB (200 g) was heated on a conventional six-flame stove by filling a pre-heated $20 \mathrm{~cm}$ diameter stainless steel pot $2 / 3$ full with sample. In this case, stabilization was performed at approximately $80{ }^{\circ} \mathrm{C}$ (high flame level) for 6 minutes, and samples were homogenized with a wooden spoon throughout the process. The heat treatments were performed in three repetitions and analyses were performed in triplicate for each heat treatment, including the untreated control sample. Final results were expressed as means for each treatment.

All collected and prepared samples were kept at room temperature to cool and then sealed in plastic bags (polypropylene) and stored in a freezer at $-12{ }^{\circ} \mathrm{C}$ for less than 24 hours until analyses. For the chemical composition evaluation, samples were milled in an analytical mill (Mill A10 S7), and passed through a 32-mesh sieve $(0.5 \mathrm{~mm})$. The moisture of the rice bran flour was determined according to method $\mathrm{n}^{\mathrm{o}} / 925.09 \mathrm{~B}$ (AOAC 1995) by weighing around $5 \mathrm{~g}$ of sample. After drying, the sample was used for the nutritional composition analyses to obtain dry basis results. The experimental design was fully randomized and results expressed as an average of the three data repetitions (mean) \pm standard deviation, with proximate composition and free fatty acid content as the study variables for both heat treatments.

All reagents used for analyses were analytical grade (P.A.). The enzymes applied for the dietary fiber analyses were: heat resistant $\alpha$-amylase (Sigma A-3306), amyloglucosidase (Sigma A-3306) and protease (Sigma P-3910). The standards used in the gas chromatography were all from Sigma (Sigma-Aldrich Corp., St. Louis, MO, USA). The following methods were used for the respective analyses:

The analysis of chemical composition based on the Official Methods of Analysis of AOAC (1995) was performed at the Department of Pharmaceutical Sciences, 
Food Science and Experimental Nutrition, the University of São Paulo - USP, Brazil, including: moisture $\left(\mathrm{n}^{\mathrm{o}} / 925.09 \mathrm{~B}\right)$; mineral fraction $\left(\mathrm{n}^{\mathrm{o}} / 923.03\right)$; total lipids $\left(\mathrm{n}^{\circ} / 920.39 \mathrm{C}\right)$; proteins $\left(\mathrm{n}^{\circ} / 960.52\right)$ and soluble and insoluble dietary fibers ( $\left.\mathrm{n}^{\circ} / 991.43\right)$ according to the enzymatic and gravimetric principle. Briefly, for this method rice bran samples were previously defatted on a Soxhlet device using ethyl ether for $8 \mathrm{~h}$ to achieve lipid extraction. Values obtained by the enzymatic method were then corrected by analyzing nitrogen content using Kjeldahl method $\mathrm{n}^{\mathrm{o}}$ / 960.52, AOAC (1995) and mineral fraction content based on method $\mathrm{n}^{\circ} / 923.03$, AOAC (1995). Total dietary fiber was calculated based on the sum of insoluble and soluble fractions, as recommended by the method.

Analysis of some minerals (zinc, iron, calcium, sodium and potassium) by Instrumental Neutron Activation Analysis (INAA) was performed at the Institute of Energy and Nuclear Research (IPEN-CNEN) in São Paulo, where samples were submitted to irradiation with neutrons and gamma activity was induced in a gamma ray spectrometer, according to Maihara et al. (2001). The AANI comparison was used, in which each sample was irradiated; two samples simultaneously, one reference material and two synthetic standards.

Fatty acid analysis was performed at the Department of Pharmaceutical Sciences, Food Science and Experimental Nutrition at the Laboratory of Lipids, the University of São Paulo - USP, Brazil. Fatty acid extraction followed the method described by Folch et al. (1957) and esterification was performed according to Hartman and Lago (1973). The analysis conditions were as follows: Gas chromatograph GC 17A from Shimadzu, equipped with a flame ionization detector (FID), automatic injector AOC-20, Workstation Class GC10 and SP-2560 fused silica capillary column (biscyanopropyl polysiloxane) $100 \mathrm{~m}$ in length $\mathrm{x} 0.25 \mathrm{~mm}$ internal diameter $\mathrm{x} 0.25 \mu \mathrm{m}$ by Supelco. Column temperature program: Isothermal at $140^{\circ} \mathrm{C}$ for 5 minutes and then heating at $4{ }^{\circ} \mathrm{C} / \mathrm{min}$ until $240{ }^{\circ} \mathrm{C}$, holding this temperature for 20 minutes. The temperature of the vaporizer was $250{ }^{\circ} \mathrm{C}$ and the detector was set at $260^{\circ} \mathrm{C}$. Helium was used as the carrier gas at 20 $\mathrm{cm} / \mathrm{s}$ and $175^{\circ} \mathrm{C}$. The sample split in the injector was $1 / 50$. One microliter of the esterified lipid extract was injected and fatty acid retention times compared to Sigma standards (Sigma-Aldrich Corp., St. Louis, MO, USA) for fatty acid methyl esters. The calculation was performed as follows: fatty acids of samples were identified by comparing their retention times with the fatty acid methyl esters standards; compared with chromatograms of the Ce 1h-05 method from AOCS (2004), and that reported by Ratnayake et al. (2002) and Ratnayake et al. (2006). The quantification of the fatty acids was done by normalization of the areas and the percentages multiplied by the Holland conversion factor (Chan et al., 1994). This factor was used to convert the content of fat into fatty acid. The conversion factor utilized was 0.956 . The quantification in grams per portion of 100 $\mathrm{g}$ was done by normalization of the area and multiplication of the lipid content and the conversion factor, with results proving identical to those observed using internal standards for some of the samples.

\section{Statistical analysis}

All data were tested for normal distribution (Shapiro-Wilk test) and for homogeneity of variance (Levene and Brown-Forsythe). Comparisons of the data of the two different heat procedures for rice bran stabilization were performed by analysis of variance (ANOVA), followed by the Tukey test. For data without normal distribution or homogeneity of variance, other non-parametric tests were applied: Mann-Whitney or Kruskal-Wallis. All statistical analyses were done using the program STATISTICA (Version 8.0 for Windows), at $5 \%(\mathrm{p}<0.05)$ probability.

\section{RESULTS AND DISCUSSION}

Table I shows the composition of the rice bran samples subjected to the different stabilization procedures. In general, results were consistent with data reported in the literature for this kind of sample, such as the study conducted by Juliano (2003).

Based on the results of Table I, the evaluation of rice bran composition subjected to two different stabilization procedures in comparison to untreated samples (WRB), showed significant differences $(p<0.05)$, indicating that the stabilization technique used modified bran composition. The roasting technique yielded samples with the lowest moisture content (RRB), suggesting that this procedure may be effective for samples with longer shelf life and less microbial contamination and some nutrient preservation. Similar results were reported by researchers from Embrapa Rice and Beans (Oliveira et al., 2006) evaluating the microbiological quality of rice bran samples subjected to thermal processing methods with similar conditions (RRB, MRB and parboiled rice bran) and stored at room temperature. The group observed that RRB samples (or MRB) showed less or complete absence of fungi or mold contamination at lower moisture content, which improved their storage time under ambient conditions, while untreated rice bran had a greater microbial load (total fungi) than all the homemade treated samples. Our results showed that both heating procedures applied for rice bran stabilization 
TABLE I - Nutritional Composition of Rice Bran Samples Subjected to Two Different Heat Stabilization Procedures (dry weight basis)*

\begin{tabular}{|c|c|c|c|}
\hline \multirow{2}{*}{ Components (in $100 \mathrm{~g}$ ) } & \multicolumn{3}{|c|}{ Bran type $e^{* *}$} \\
\hline & WRB & MRB & RRB \\
\hline Moisture (g) & $8.41 \pm 0.2^{\mathrm{a}}$ & $6.28 \pm 0.10^{\mathrm{Ab}}$ & $5.14 \pm 0.10^{\mathrm{Bb}}$ \\
\hline Mineral Fraction (g) & $8.13 \pm 0.04^{\mathrm{a}}$ & $6.98 \pm 0.04^{\mathrm{Bb}}$ & $8.52 \pm 0.02^{\mathrm{Aa}}$ \\
\hline Total lipids (g) & $17.87 \pm 0.30^{\mathrm{b}}$ & $20.05 \pm 0.40^{\mathrm{Aa}}$ & $18.34 \pm 0.10^{\mathrm{Ab}}$ \\
\hline Proteins (Gn x 5.95) & $16.61 \pm 0.20^{\mathrm{b}}$ & $19.38 \pm 0.30^{\mathrm{Aa}}$ & $18.93 \pm 0.20^{\mathrm{Aa}}$ \\
\hline Insoluble fiber (g) & $22.67 \pm 0.41^{\mathrm{b}}$ & $24.64 \pm 0.23^{\mathrm{Aa}}$ & $20.34 \pm 0.21^{\mathrm{Bc}}$ \\
\hline Soluble fiber (g) & $1.48 \pm 0.02^{\mathrm{a}}$ & $0.74 \pm 0.24^{\mathrm{Ab}}$ & $0.11 \pm 0.01^{\mathrm{Bb}}$ \\
\hline Total dietary fiber (g) & $24.15^{\mathrm{b}}$ & $25.38^{\mathrm{Aa}}$ & $20.45^{\mathrm{Bc}}$ \\
\hline Available carbohydrates ${ }^{\#}(\mathrm{~g})$ & $33.24^{\mathrm{b}}$ & $28.21^{\mathrm{Aa}}$ & $33.76^{\mathrm{Cb}}$ \\
\hline Energy & $423.19^{\mathrm{b}}$ & $447.21^{\mathrm{Aa}}$ & $437.06^{\mathrm{Ba}}$ \\
\hline Calcium $(\mu \mathrm{g} / \mathrm{g})$ & $438 \pm 41^{b}$ & $733 \pm 186^{\mathrm{a}}$ & n.d \\
\hline Iron $(\mu \mathrm{g} / \mathrm{g})$ & $94 \pm 0.0^{\mathrm{b}}$ & $115 \pm 7^{\mathrm{Aa}}$ & $115 \pm 7^{\text {Аa }}$ \\
\hline Sodium $(\mu \mathrm{g} / \mathrm{g})$ & $17 \pm 2^{\mathrm{a}}$ & $12 \pm 1^{\mathrm{Bb}}$ & $15 \pm 2^{\mathrm{Ab}}$ \\
\hline $\operatorname{Zinc}(\mu \mathrm{g} / \mathrm{g})$ & $72 \pm 5^{b}$ & $140 \pm 10^{\mathrm{Aa}}$ & $84 \pm 7^{\mathrm{Ba}}$ \\
\hline Potassium $(\mu \mathrm{g} / \mathrm{g})$ & $11.293 \pm 960^{\mathrm{b}}$ & $5.418 \pm 305^{\mathrm{Bc}}$ & $15.824 \pm 355^{\mathrm{Aa}}$ \\
\hline 16:0 palmitic acid (g) & $2.73 \pm 0.34^{\mathrm{b}}$ & $2.85 \pm 0.01^{\mathrm{Ab}}$ & $2.46 \pm 0.01^{\mathrm{Cb}}$ \\
\hline 18:0 stearic acid (g) & $0.37 \pm 0.02^{\mathrm{b}}$ & $0.51 \pm 0.00^{\mathrm{Aa}}$ & $0.34 \pm 0.00^{\mathrm{Cb}}$ \\
\hline 18:1 oleic acid $(\mathrm{g})$ & $6.86 \pm 0.03^{\mathrm{b}}$ & $8.14 \pm 0.03^{\mathrm{Aa}}$ & $6.91 \pm 0,02^{\mathrm{Bb}}$ \\
\hline 18:2 linoleic acid (g) & $6.35 \pm 0.29^{b}$ & $6.85 \pm 0.03^{\mathrm{Aa}}$ & $6.84 \pm 0.02^{\mathrm{Aa}}$ \\
\hline 18:3 $\alpha$-linolenic acid $(\mathrm{g})$ & $0.26 \pm 0.03^{\mathrm{b}}$ & $0.20 \pm 0.00^{\mathrm{cb}}$ & $0.27 \pm 0.00^{\mathrm{Aa}}$ \\
\hline
\end{tabular}

Results in triplicate, and dietary fiber in quadruplicate, for each repetition.

${ }^{\text {** }}$ WRB: Whole rice bran; MRB: Whole rice bran treated in microwave oven; RRB: Whole rice bran roasted on conventional stove.

\# Calculated by difference: total carbohydrate ( $100 \mathrm{~g}$ - total in $\mathrm{g}$ proteins, lipids and mineral fraction $)$ - total dietary fiber.

Each value represents the mean and \pm standard deviation of triplicates of three repetitions; Comparison between the untreated and the stabilized samples (microwave oven and conventional stove) was performed by ANOVA followed by Tukey's test or by Kruskal-Wallis test using the software STATISTICA (2007).

*Values followed by different lower case letters on same line indicate statistically significant difference between treated samples and control ( $\mathrm{p}<0.05$ ); Values followed by different upper case letters on same line indicate statistically significant difference between treated samples $(\mathrm{p}<0.05)$. n.d $=$ not detected

contributed toward concentrating most nutrients of the raw bran (Table I). However, the procedures affected the rice bran's final nutritional composition differently. For instance, the MRB generally presented better nutrient preservation especially considering total lipids, proteins and insoluble and soluble fiber content as well as some fatty acids (palmitic acid, stearic acid and oleic acid) and minerals (calcium and zinc) levels. On the other hand, the RRB affected sodium and potassium levels, concentrating their fractions in treated rice bran. For some nutrients such as iron and linoleic acid, both heating methods had the same preserving effects.

It is important to point out that both heat treatments produced rice bran in the form of a product with a good source of proteins and fiber. A single portion (usually 10 g) of either rice bran (MRB or RRB) contained more than $18 \%$ protein, representing $3.8 \%$ of the daily recommended protein for a diet of $2,000 \mathrm{kcal}$ or $8,400 \mathrm{~kJ}$. The same bran portion provided around $10 \%$ of the reference daily value for the same diet (FAO/WHO, 2011). Since it may be considered a good source of fiber, rice bran should give the same nutritional and functional benefits as the component (Abdul-Hamid, Luan, 2000).

Results obtained regarding variation of nutrient contents showed significant differences in lipid composition $(\mathrm{p}<0.05)$ in all samples analyzed, a disparity which can be attributed to the heat processes used. As previously reported by other authors, different stabilization tech- 
niques may reduce enzymatic activity to a greater or lesser degree, resulting in increased or decreased oil extraction (Lakkakula et al., 2004). Furthermore, different stabilization processes using high temperature $\left(\geq 100{ }^{\circ} \mathrm{C}\right)$ such as extrusion can significantly reduce the rice bran oil quality. This occurs by diminishing the contents of many valuable and heat sensitive compounds, such as the antioxidant activity of oryzanols, tocopherols and tocotrienols, present in non-stabilized rice bran or rice bran oil with proven health benefits (Lloyd et al., 2000).

Considering the present work, given the milling process of rice grain followed the same pattern for all samples, the variation in proximate composition of rice bran samples was not due to milling degree as claimed by some authors (Amissah et al., 2003). On the other hand, the influence of different processing methods for stabilization on the nutritional quality of rice bran for human consumption was previously reported by Silva et al. (2006), who showed that the parboiling process produced more stable rice bran when compared to control samples. Thus, in the present work, the nutritional variation between samples is attributable to the heat treatments applied as opposed to the rice milling process used.

Given the importance of rice as a food source, research has been conducted to increase the concentration of minerals in the grain, particularly iron and zinc, two essential minerals for human health (Walter et al., 2008). These minerals are generally more concentrated in the outer layers of rice grain, being mainly distributed between rice bran (around 72\%) and rice endosperm or white rice (around 28\%) (Juliano, 2003). It is well known that mineral content is strongly influenced by cultivation conditions, including soil structure condition and fertilization, as well as by rice processing (Walter et al., 2008). Furthermore, the present work appears to indicate that different stabilization techniques may also alter rice bran mineral content. However, the possibility of interaction between the pot composition and the rice bran during toasting has not been ruled out. Previous work (Lacerda et al., 2010) for instance, reported that an enrichment of iron into the product could occur during rice bran extrusion due to friction of raw material rich in fiber with some extruder components. Other reasons for the observed mineral differences may be related to contamination sources during processing or methodological uncertainty. On the other hand, total mineral content remained statistically the same between control and RRB samples, except for MRB (Table 1). Further studies on mineral bioavailability to check the effects of the stabilization methods are warranted.

Fatty acid results obtained in this study were in agreement with those reported by Kim et al. (1999), in which more than $70 \%$ of the fatty acids present in the bran oil were unsaturated, with oleic predominating, followed by linoleic and $\alpha$-linolenic acid. The others detected were saturated fatty acids, mainly palmitic and stearic. The results presented indicate that different heat treatments can significantly change the fatty acid profile $(\mathrm{p}<0.05)$. The RRB samples showed losses of palmitic $(9.9 \%)$ and stearic $(8.1 \%)$ fatty acids. Rice bran is a natural source of lipids, and can contain more than $20 \%$ its weight in oil, especially unsaturated fatty acids, besides having bioactive phytochemical content such as oryzanol and tocotrienols known for their functional properties with proven health benefits (Silva et al., 2006; Reshma et al., 2007). On this aspect, studies developing methods of stabilization of the bran that improve the efficiency of oil extraction and preservation of the compounds present have been conducted. The study reported by Lakkakula et al. (2004) for instance, analyzed the effect that ohmic heating for enzymatic inactivation exerted on rice bran oil. In the cited study, ohmic heating (electrical heating) was applied to stabilize rice bran in order to improve the production of oil extraction compared to microwave heating and a control sample (not heated, crude). Their results showed that ohmic heating and microwave heating were both successful methods for stabilizing rice bran.

Our WRB sample seemed to have more fatty acid liberation due to heating and might need greater attention to its storage conditions in order to avoid or reduce the development of rancidity.

\section{CONCLUSIONS}

The results obtained in this study allow the following conclusions to be drawn:

- Distinct rice bran stabilization procedures can change the content of some nutrients by varying degrees;

- In general, the nutritional quality was practically fully preserved in both treated rice bran samples, with a few exceptions for some components;

- The roasting process reduced the bran moisture more efficiently but appears to constitute a more severe treatment for the conservation of some fatty acids;

- Microwave oven treatment represents a practical tool for rice bran heat stabilization and reaps more advantage of oil compounds considered beneficial to human health.

\section{ACKNOWLEDGEMENTS}

The authors would like to thank São Paulo Teaching and Research Foundation Support - Fundação de Amparo 
à Pesquisa do Estado de São Paulo (FAPESP), and the Scientific and Technological Development National Council - Conselho Nacional de Desenvolvimento Cientifico e Tecnológico (CNPq) for their financial support. The authors are also grateful for the technical assistance provided by the researchers Dr. Daniela Borrmann from the Faculty of Pharmaceutical Sciences - University of São Paulo, Selma Nakamoto Koakuzu and Marcia Gonzaga Castro from Embrapa Rice and Beans, and Dr. Déborah Inês Fávaro from the Institute of Energy and Nuclear Research (IPEN-CNEN) in São Paulo for her assistance on the mineral analysis.

\section{REFERENCES}

ABDUL-HAMID, A.; LUAN, Y.S. Functional properties of dietary fibre prepared from defatted rice bran. Food Chem., v.68, n.1, p.15-19, 2000.

AMERICAN OIL CHEMISTS' SOCIETY. Official methods and recommended practices of the American Oil Chemists' Society. 5.ed. Champaign: AOCS, 2004. Section C, p.1-29 (Method Ce 1h-05).

AMISSAH, J.G.N.; ELLIS, W.O.; ODURO, I.; MANFUL, J.T. Nutrient composition of bran from new rice varieties under study in Ghana. Food Control, v.14, n.1, p.21-24, 2003.

ASSOCIATION OF OFFICIAL ANALYTICAL CHEMISTS. Official methods of analysis of AOAC international. 16.ed. Arlington: AOAC, 1995. cap.4, p.17; cap.12, p.7; cap.32, p.1; cap.32, p.2, p.7. (Methods n.920.39C; n.960.52; n.925.09B; n.923.03; n.991.43).

CARVALHO, J.L.V.; BASSINELLO, P.Z. Aproveitamento industrial. In: SANTOS, A.B.; STONE, L.F.; VIEIRA, N.R.A. (Eds.). A cultura do arroz no Brasil. 2.ed. Santo Antônio de Goiás: Embrapa Arroz e Feijão, 2006. p.901931.

CHAN, W.; McCANCE, R.A.; BUSS, D.H.; BROWN, J. McCance and Widdowson's the composition of foods. 5.ed. Cambridge: Royal Society of Chemistry and Ministry of Agriculture, Fisheries and Food, 1994. 193 p.

FOLCH, J.; LEES, M.; SLOANE STANLEY, G.H. A simple method for the isolation and purification of total lipids from animal tissues. J. Biol. Chem., v.226, n.1, p.497-509, 1957.
FOOD AND AGRICULTURE ORGANIZATION OF THE UNITED NATIONS; WORLD HEALTH ORGANIZATION. Human vitamin and mineral requeriments: report of a joint FAO/WHO expert consultation, Bangkok, Thailand. Rome: FAO, Food and Nutrition Division, 2001. 303 p. Available at: <ftp://ftp.fao.org/es/esn/nutrition/Vitrni/vitrni.html>. Accessed on: 20 apr. 2011.

HARTMAN, L.; LAGO, R.C.A. Rapid preparation of fatty acid methyl ester from lipids. Lab. Practice, v.22, n.6, p.475476, 1973.

IMSANGUAN, P.; ROAYSUBTAWEE, A.; BORIRAK, R.; PONGAMPHAI, S.; DOUGLAS, S.; DOUGLAS, P.L. Extraction of $\alpha$-tocopherol and y-oryzanol from rice bran. LWT - Food Sci. Technol., v.41, n.8, p.1417-1424, 2008.

JULIANO, B.O. Rice: chemistry and quality. Muñoz: Philippine Rice Research Institute, 2003. 480 p.

KIM, H.-J.; LEE, S.-B.; PARK, K.-A.; HONG, I.-K. Characterization of extraction and separation of rice bran oil rich in EFA using SFE process. Sep. Purif. Technol., v.15, n.1, p.1-8, 1999.

LACERDA, D.B.C.L.; SOARES JR., M.S.; BASSINELLO, P.Z.; CASTRO, M.V.L.; SILVA-LOBO, V.L.; CAMPOS, M.R.H.; SIQUEIRA, B.S. Qualidade de farelos de arroz cru, extrusado e parboilizado. Pesqui. Agropecu. Trop., v.40, n. 4 , p.521-530, 2010.

LAKKAKULA, N.R.; LIMA, M.; WALKER, T. Rice bran stabilization and rice bran oil extraction using ohmic heating. Bioresource Technol., v.92, n.2, p.157-161, 2004.

LILITCHAN, S.; TANGPRAWAT, C.; ARYUSUK, K.; KRISNANGKURA, S.; CHOKMOH, S.; KRISNANGKURA, K. Partial extraction method for the rapid analysis of total lipids and y-oryzanol contents in rice bran. Food Chem., v.106, n.2, p.752-759, 2008.

LLOYD, B.J.; SIEBENMORGEN, T.J.; BEERS, K.W. Effects of commercial processing on antioxidants in rice bran. Cereal Chem., v.77, n.5, p.551-555, 2000.

MAIHARA, V.A.; FÁVARO, D.I.; SILVA, V.N.; GONZAGA, I.B.; SILVA, V.L.; CUNHA, I.I.L.; VASCONCELLOS, M.B.A.; COZZOLINO, S.M.F. Determination of mineral constituents in duplicate portion diets of two university student groups by instrumental neutron activation analysis. J. Radioanal. Nucl. Chem., v.249, n.1, p.21-24. 2001. 
OLIVEIRA, M.G.C.; BASSINELLO, P.Z.; SILVA-LOBO, V.L.; RINALDI, M.M.; CARMO, E.J.S. Avaliação visual e umidade de farelo de arroz proveniente de diferentes fontes. Santo Antônio de Goiás: Embrapa Arroz e Feijão, 2006. Available at: <http://ainfo.cnptia.embrapa.br/digital/ bitstream/CNPAF/23644/1/CBC-TRAB_64-2.pdf $>$. Accessed on: 18 Sept. 2008.

PAN, Z.; CATHCART, A.; WANG, D. Thermal and chemical treatments to improve adhesive property of rice bran. Ind. Crop. Prod., v.22, n.3, p.233-240. 2005.

PARRADO, J.; MIRAMONTES, E.; JOVER, M.; GUTIERREZ, F.C.O.J.; TERÁN, C.L.; BAUTISTA, J. Preparation of a rice bran enzymatic extract with potential use as functional food. Food Chem., v.98, n.4, p.742-748, 2006.

PAUCAR-MENACHO, L.M.; SILVA, L.H.; SANT'ANA, A.S.; GONÇALVES, L.A.G. Refining of rice bran oil (Oryza sativa L.) to preserve y-orizanol. Ciênc. Tecnol. Aliment., v.27, sup.1, p.45-53. 2007.

RAMEZANZADEH, F.M.; RAO, R.M.; WINDHAUSER, M.; PRINYAWIWATKUL, W.; TULLEY, R.; MARSHALL, W.E. Prevention of hydrolytic rancidity in rice bran during storage. J. Agric. Food Chem., v.47, n.8, p.3050-3052, 1999.

RATNAYAKE, W.M.N.; HANSEN, S.L.; KENNEDY, M.P. Evaluation of the CP-Sil 88 and SP-2560 GC columns used in the recently approved AOCS official method Ce 1h-05: determination of cis-, trans-, saturated, monounsaturated, and polyunsaturated fatty acids in vegetable or nonruminant animal oils and fats by capillary GLC method. $J$. AOAC Int., v.83, n.6, p.475-488, 2006.

RATNAYAKE, W.M.N.; PLOUFFE, L.J.; PASQUIER, E.; GAGNON, C. Temperature-sensitive resolution of cis- and trans-fatty acid isomers of partially hydrogenated vegetable oils on SP-2560 and CP-Sil 88 capillary columns. J. AOAC Int., v.85, n.5, p.1112-1118, 2002.
RENUKA, D.R.; ARUMUGHAN, C. Antiradical efficacy of phytochemical extracts from defatted rice bran. Food Chem. Toxicol., v.45, n.10, p.2014-2021, 2007.

RESHMA, M.V.; SARITHA, S.S.; BALACHANDRAN, C.; ARUMUGHAN, C. Lipase catalyzed interesterification of palm stearin and rice bran oil blends for preparation of zero trans shortening with bioactive phytochemicals. Bioresource Technol., v.99, n.11, p.5011-5019, 2007.

SILVA, M.A.; SANCHES, C.; AMANTE, E.R. Prevention of hydrolytic rancidity in rice bran. J. Food Eng., v.75, n.4, p.487-491, 2006.

STATISTICA. Version 8.0 for Windows. StatSoft: Tulsa, v.1, 2007.

SUMANTHA, A.; DEEPA, P.; SANDHYA, C.; SZAKACS, G.; SOCCOL, C.R.; PANDEY, A. Rice bran as a substrate for proteolytic enzyme production. Braz. Arch. Biol. Technol., v.49, n.4, p.843-851, 2006.

WADA, H.K. Avaliação do farelo de arroz irradiado como fonte de ferro. São Paulo, 2001. 57 p. [Dissertation of Master degree. Faculty of Pharmaceutical Sciences. Univerty of São Paulo].

WALTER, M.; MARCHEZAN, E.; AVILA, L.A. Arroz: composição e características nutricionais. Ciênc. Rural, v.38, n.4, p.1184-1192, 2008.

XU, Z.; GODBER, J.S. Purification and identification of components of y-oryzanol in rice bran oil. J. Agr. Food Chem., v.47, n.7, p.2724-2728, 1999.

Received for publication on $24^{\text {th }}$ January 2012 Accepted for publication on $20^{\text {th }}$ July 2012 